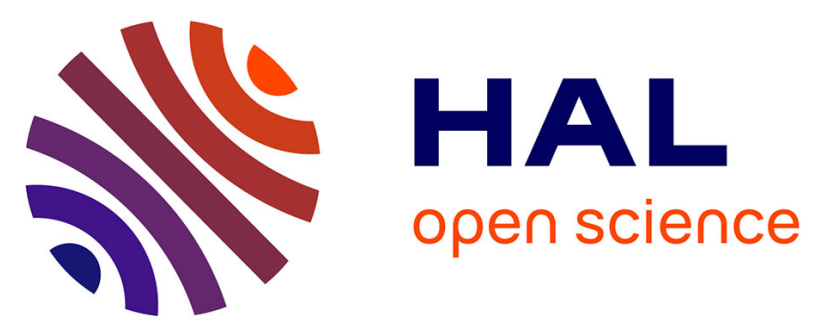

\title{
Fipronil-induced disruption of thyroid function in rats is mediated by increased total and free thyroxine clearances concomitantly to increased activity of hepatic enzymes
}

\author{
Julien Leghait, Véronique V. Gayrard-Troy, Nicole Picard-Hagen, Marion \\ Camp, Elisabeth Perdu, Pierre-Louis Toutain, Catherine Viguié
}

\section{To cite this version:}

Julien Leghait, Véronique V. Gayrard-Troy, Nicole Picard-Hagen, Marion Camp, Elisabeth Perdu, et al. Fipronil-induced disruption of thyroid function in rats is mediated by increased total and free thyroxine clearances concomitantly to increased activity of hepatic enzymes. Toxicology, 2009, 255 (1-2), pp.38-44. 10.1016/j.tox.2008.09.026 . hal-02666328

\section{HAL Id: hal-02666328 \\ https://hal.inrae.fr/hal-02666328}

Submitted on 31 May 2020

HAL is a multi-disciplinary open access archive for the deposit and dissemination of scientific research documents, whether they are published or not. The documents may come from teaching and research institutions in France or abroad, or from public or private research centers.
L'archive ouverte pluridisciplinaire HAL, est destinée au dépôt et à la diffusion de documents scientifiques de niveau recherche, publiés ou non, émanant des établissements d'enseignement et de recherche français ou étrangers, des laboratoires publics ou privés. 


\title{
Fipronil-induced disruption of thyroid function in rats is mediated by increased total and free thyroxine clearances concomitantly to increased activity of hepatic enzymes
}

\author{
Leghait Julien ${ }^{\mathrm{a}}$, Gayrard Véronique ${ }^{\mathrm{a}}$, Picard-Hagen Nicole ${ }^{\mathrm{a}}$, Camp Marion ${ }^{\mathrm{a}}$, \\ Perdu Elisabeth ${ }^{\mathrm{b}}$, Toutain Pierre-Louis ${ }^{\mathrm{a}}$, Viguié Catherine ${ }^{\mathrm{a}, *}$ \\ a UMR181 Physiopathologie et Toxicologie Expérimentales, INRA, ENVT, 23 Chemin des Capelles, BP 87614, 31076 Toulouse Cedex 3, France \\ b UMR1089 Xénobiotiques, INRA, ENVT, 180 Chemin de Tournefeuille, BP 3, 31931 Toulouse Cedex 9, France
}

\section{A R T I C L E I N F O}

\section{Article history:}

Received 7 August 2008

Received in revised form

26 September 2008

Accepted 29 September 2008

Available online 9 October 2008

\section{Keywords}

Thyroid disruptor

Rat

Clearance

UDPGT

Fipronil

5-Amino-1-[2,6-dichloro-4-

(trifluoromethyl)phenyl]-4-

(trifluoromethylsulfinyl)-1H-pyrazole-3-

carbonitrile

\begin{abstract}
A B S T R A C T
Fipronil is a widely used phytosanitary product and insecticide for pets. In the rat, fipronil can disrupt thyroid function by decreasing plasma concentrations of total thyroxine (T4) likely through increased T4 clearance. However, the mechanism of fipronil action on thyroid function remains unclear. The goals of the present study were to evaluate the effects of fipronil on thyroid hormone $(\mathrm{TH})$ concentrations and elimination in the rat under well characterized plasma exposure to fipronil and its main metabolite fipronil sulfone. In thyroid-intact female rats, fipronil treatment ( $3 \mathrm{mg} /(\mathrm{kg}$ day) per os for 14 days) decreased both total and free TH plasma concentrations concomitantly to increased thyroid stimulating hormone plasma concentrations. A T4-free euthyroid-like model consisting of thyroidectomized rats treated with tri-iodothyronine ( $12 \mu \mathrm{g} /(\mathrm{kg}$ day $)$, sc) was developed to evaluate both total and free T4 clearances. In this model, fipronil treatment induced a twofold increase in total and free T4 clearances. The same fipronil treatment increased antipyrine clearance in thyroid-intact rats suggesting an increase in the activity of cytochrome P450 enzymes. Finally, this treatment was also associated with an increase in hepatic microsomal 4-nitrophenol UDP-glucuronosyltransferase activity involved in T4 glucuronidation. Thus, fipronil-induced thyroid disruption results from an increased rate of T4 elimination likely mediated by increased hepatic enzyme activity. Plasma concentrations of fipronil sulfone were at least 20 -fold higher than those of fipronil. This highlights the need to further investigate the contribution of fipronil sulfone to the fipronil-induced thyroid disruption.
\end{abstract}

(c) 2008 Elsevier Ireland Ltd. All rights reserved.

\section{Introduction}

Fipronil is a pesticide of the phenylpyrazole family widely used as a phytosanitary product and as an insecticide in pets (Tingle et al., 2003). To date, the only available data on fipronil toxicology are non-peer reviewed results of studies performed in rats by the pharmaceutical industry for legal requirements (FAO/WHO, 1997; AFSSA, 2005). These studies have shown that fipronil exhibits thyroid disrupting properties in rats. Indeed, in this species, fipronil treatment ( $17 \mathrm{mg} /(\mathrm{kg}$ day) po for 91 weeks) was associated with a significant increase in the incidence of thyroid gland tumors concomitant with increased plasma con-

\footnotetext{
* Corresponding author at: UMR181 Physiopathologie et Toxicologie Expérimentales, INRA, ENVT, 23 Chemin des Capelles, BP 87614, 31076 Toulouse Cedex 3, France. Tel.: +33 561193913; fax: +33 561193917 .

E-mail address: c.viguie@envt.fr (C. Viguié).
}

centrations of thyroid stimulating hormone (TSH) and decreased thyroxine (T4) concentrations (FAO/WHO, 1997). Decreased total T4 plasma concentrations were also observed at fipronil doses as low as $0.078 \mathrm{mg} /(\mathrm{kg}$ day) and after as little as 7 days of treatment. In addition, fipronil (10 $\mathrm{mg} /(\mathrm{kg}$ day) for 14 days) increased $\left[{ }^{125} \mathrm{I}\right] \mathrm{T} 4$ body clearance at least in part through increased T4 biliary elimination (FAO/WHO, 1997; Hurley, 1998). The following hypothetical pathophysiological scheme was put forward to explain these results: fipronil would induce hepatic enzymes responsible for T4 catabolism resulting in increased T4 clearance which would account for the reduced plasma concentrations of total T4. This decrease in T4 plasma concentrations would be responsible for an increase in TSH secretion due to a suppressed T4 negative feedback on TSH secretion. In rats, prolonged exposure of the thyroid to elevated TSH levels has been shown to favour the development of follicular tumors (Williams, 1995; Hurley, 1998; Hood et al., 1999).

However, the diverse effects and mechanisms of action of fipronil on thyroid function were studied under different condi- 
tions of treatment in terms of dose and duration and the validity of this pathophysiological scheme is therefore open to question. The decrease in T4 plasma concentrations was actually observed at a lower dose and shorter duration than the increased T4 clearance $(0.078 \mathrm{mg} /(\mathrm{kg}$ day) $v s .10 \mathrm{mg} /(\mathrm{kg}$ day) and 7 days $v s .14$ days $)$ so that a cause-effect relationship between these two observations cannot definitely be established. Moreover, as T4 clearance was determined with radiolabeled $\mathrm{T} 4$, the effect of fipronil on the clearance of free T4, the form of T4 accessible to cells, could not be assessed (Abend et al., 1991). Another major limit of all these toxicological evaluations is that exposure to fipronil, i.e. plasma concentrations of fipronil and its main metabolite fipronil sulfone (Tang et al., 2004), was never characterized. Thus, the relevance of rat fipronil exposure to possible human exposure could not be evaluated. Indeed, detailed quantitative characterization of the exposure is the only way to determine whether the exposure observed in animal experiments is similar to that encountered in exposed human populations. Finally, the proposed pathophysiological scheme assumed that fipronil could act as a hepatic enzyme inducer that would increase T4 hepatic catabolism although most in vitro or ex vivo data concerning this point are conflicting. In vitro, fipronil increases CYP1A1 and 3A4 activities in human hepatocytes (Das et al., 2006) which is consistent with a possible induction effect of fipronil on hepatic enzymes. In contrast, no clear effect of fipronil was evidenced on the activities of microsomes obtained from fipronil-treated rats, rabbits or mice ( 1.2 or $5 \mathrm{mg} /(\mathrm{kg}$ day) for 4 or 14 days) (AFSSA, 2005).

The goals of this study were to document the pathophysiological scheme of action of fipronil as a thyroid disruptor in the rat under well characterized conditions of exposure to fipronil and fipronil sulfone. The effect of fipronil on both free and total T4 clearances was specifically investigated in an original T4-free euthyroid-like model and the possibility that fipronil could increase the activity of both phase I and UDP-glucuronosyltransferases (UDPGT) hepatic enzymes was tested.

\section{Methods}

\subsection{Animals - surgery - blood samples}

The study was performed on 9-week-old Wistar female rats ( $250 \mathrm{~g}$ body weight (BW)) purchased from Janvier (Le Genest Saint Isle, France) or Charles River (L'Arbresle, France). The rats were housed 2-3 per cage at room temperature with an inversed $12 \mathrm{~h} \mathrm{light/dark} \mathrm{cycle} \mathrm{(lights} \mathrm{off} \mathrm{at} \mathrm{10:00} \mathrm{a.m.)} \mathrm{and} \mathrm{were} \mathrm{acclimated} \mathrm{for} \mathrm{at}$ least 2 weeks before the beginning of the experiments. The rats had free access to food (Harlan, T2016, Gannat, France) and tap water and were weighed twice a week.

Serial blood samples were collected through cannulae surgically inserted in the left femoral vein under ketamine/medetomidine (Imalgene ${ }^{\circledR} 1000$, Merial SAS, Villeurbanne, France/Domitor ${ }^{\circledR}$, Pfizer, Paris, France) anaesthesia (50 and $0.2 \mathrm{mg} / \mathrm{kg}$, respectively) at least 3 days before the experiments. When the rats were thyroidectomized (THX), thyroidectomy and vein cannulation were performed simultaneously 1 week before the beginning of fipronil treatment. During the postsurgical stage, THX rats received a daily sc injection of Ringer lactate solution ( $5 \mathrm{ml} /$ day, B Braun Medical, Boulogne, France) for 1 week and a daily sc injection of sulfadoxine $(7.5 \mathrm{mg} / \mathrm{kg})$ and trimethoprime $\left(1.5 \mathrm{mg} / \mathrm{kg}\right.$ ) (Borgal ${ }^{\circledR}$, Intervet S.A., Angers, France) for 2 days.

After each serial blood sample, a volume of physiological saline equivalent to the collected blood volume was administered, followed by $200 \mu \mathrm{l}$ of heparinized saline $(50 \mathrm{IU} / \mathrm{ml})$. Blood samples were centrifuged at $3000 \times \mathrm{g}$ for $15 \mathrm{~min}$ at $4{ }^{\circ} \mathrm{C}$ and plasma was stored at $-20^{\circ} \mathrm{C}$ until assayed. For the first three experiments, the fipronil and fipronil sulfone plasma concentrations were determined in blood samples collected about $25 \mathrm{~h}$ after the last fipronil administration in experiment 1 , and $7 \mathrm{~h}$ after the last fipronil administration in experiments 2 and 3.

All animal procedures were conducted in accordance with accepted standards of humane animal care under the agreement number 31-242 for animal experimentation from the French Ministry of Agriculture.

\subsection{Test material, chemicals and fipronil treatment}

Chemicals were purchased from Sigma-Aldrich (Saint-Quentin Fallavier, France) unless otherwise specified. Tri-iodothyronine (T3) and T4 concentrated solutions
$(1 \mathrm{mg} / \mathrm{ml}$ ) were prepared by dissolution in $\mathrm{NaOH} 0.4 \mathrm{M}$-ethanol $60 \%$. The final $\mathrm{T} 3$ solution $(10 \mu \mathrm{g} / \mathrm{ml})$ used for sc injections was obtained by diluting 100 -fold in saline containing $49.4 \mathrm{mg} / \mathrm{ml}$ of sodium bicarbonate. The T4 solution used for the kinetic trial $(10 \mu \mathrm{g} / \mathrm{ml})$ was prepared by 100 -fold dilution of the concentrated solution in $10 \mathrm{mM}$ phosphate buffered saline $\mathrm{pH} 7.4$ containing $0.1 \%(\mathrm{w} / \mathrm{v})$ of bovine serum albumin. Antipyrine was extemporaneously dissolved in conditioned sterile water to obtain a final concentration of $30 \mathrm{mg} / \mathrm{ml}$.

Fipronil (lot no. B20050318, purity 95.6\%) was purchased from 3B Medical Systems Inc. (Libertyville, IL, USA). The same fipronil treatment based on daily intragastric administration of a fipronil suspension was used for all the experiments of this study. The vehicle consisted of an aqueous methyl cellulose $(0.5 \%, \mathrm{w} / \mathrm{w})$ and Tween $80(0.01 \%, \mathrm{w} / \mathrm{v})$ solution. The fipronil suspension $(1.5 \mathrm{mg} / \mathrm{ml})$ was stirred protected from light before each administration. The rats received a daily administration of vehicle or fipronil ( $3 \mathrm{mg} /(\mathrm{kg}$ day)) through feeding needles for 14 days and, in experiment 1 only, for 28 days. The volume of suspension to be administered was adjusted to the most recently recorded BW.

\subsection{Experiment 1: effect of fipronil on thyroid hormone (TH) and TSH plasma concentrations}

This experiment was performed on 28 adult female rats with an average BW ( \pm S.D.) of $255 \pm 8 \mathrm{~g}$ at the beginning of the experiment. The animals were allocated to four groups ( $n=7$ each). Two groups were treated with fipronil as described above for 14 and 28 days, respectively. The two other groups were controls and received vehicle for the same durations. The animals were rapidly euthanized by decapitation $25-25.5 \mathrm{~h}$ after the last fipronil administration and total blood was collected. The blood sample was collected from the first rat 45 min after the beginning of the dark phase and blood sampling of control and fipronil-treated animals was alternated.

\subsection{Experiment 2: effect of fipronil on T4 pharmacokinetic (PK) parameters}

Twenty rats received from the supplier were allocated to control $(n=10)$ or fipronil-treated $(n=10)$ groups. Two fipronil-treated rats died during surgery. A T4free euthyroid-like model was developed to evaluate the effect of fipronil on total and free T4 clearances. THX rats were treated with daily T3 injections ( $12 \mu \mathrm{g} /(\mathrm{kg}$ day), sc) starting $24 \mathrm{~h}$ after thyroidectomy and repeated every day until the end of the experiment to restore a T3 concentration as close as possible to the physiological one. Twenty-four hours after the last fipronil administration, rats received an i.p. bolus of T4 $(10 \mu \mathrm{g} / \mathrm{kg})$. Blood $(250 \mu \mathrm{l})$ was collected the day before, $0.25,1,2,4,8$, 23 and $28 \mathrm{~h}$ after $\mathrm{T} 4$ administration to monitor the time course of the disposition of T4 plasma concentrations.

\subsection{Experiment 3: effect of fipronil on antipyrine PK parameters}

The in vivo effect of fipronil on the phase I hepatic enzymes was assessed by studying the effect of fipronil treatment on the PK parameters of antipyrine, a probe widely used to test the oxidative capacity of the liver (Tanaka et al., 1985) and more generally the activity of cytochrome P450 enzymes (Matthew and Houston, 1990).

Twenty rats received from the supplier were allocated to control $(n=10)$ or fipronil-treated $(n=10)$ groups. Two controls and one fipronil-treated rat died during surgery. Twenty-four hours after the last fipronil administration, antipyrine PK parameters were evaluated by monitoring the disposition of antipyrine plasma concentrations after an i.p. administration of antipyrine $(30 \mathrm{mg} / \mathrm{kg})$. Blood $(250 \mu \mathrm{l})$ was collected the day before, $0.5,1,2,3,5$, 7 , and $9 \mathrm{~h}$ after the administration of antipyrine.

\subsection{Experiment 4: effect of fipronil on UDPGT activity toward 4-nitrophenol}

As UDPGT enzymes responsible for glucuronidation of 4-nitrophenol are also involved in T4 glucuronidation (Visser et al., 1993a), the effect of fipronil treatment on UDPGT activity toward 4-nitrophenol was investigated. Twenty rats randomly allocated to two groups of 10 rats were administered vehicle or fipronil ( $3 \mathrm{mg} /(\mathrm{kg}$ day), po) for 14 days. The day after the end of treatment, the rats were killed by $\mathrm{CO}_{2}$ followed by exsanguination. Three pieces of liver were immediately removed and stored at $-80^{\circ} \mathrm{C}$ after rapid freezing in liquid nitrogen. Microsomes were prepared as previously described (Zalko et al., 2006) and protein content was determined by the method of Lowry et al. (1951) with bovine serum albumin as a standard. 4-nitrophenol UDPGT activity was assayed as previously described (Burchell and Weatherill, 1981). Briefly, 4-nitrophenol ( $250 \mathrm{nM})$ was incubated at $37^{\circ} \mathrm{C}$ with $2 \mathrm{mg}$ of microsomal protein in a final solution concentration of Tris-maleate $0.25 \mathrm{M} \mathrm{pH}$ 7.4; $\mathrm{MgCl}_{2} 5 \mathrm{mM}$ and UDP glucuronic acid $4 \mathrm{mM}$. The reaction was stopped after $1 \mathrm{~h}$ with $1 \mathrm{ml}$ of trichloroacetic acid $0.5 \mathrm{M}$. Eight hundred $\mu \mathrm{l}$ of the supernatant was mixed with the same volume of $\mathrm{NaOH} 2 \mathrm{M}$ and $4.4 \mathrm{ml}$ of distilled water. The glucuronidation of 4-nitrophenol was quantified by the decrease in absorbance at $405 \mathrm{~nm}$

\subsection{Thyroid hormone assays}

Total and free T4 and T3 plasma concentrations were determined using radioimmunoassay kits from Diagnostic Products Corporation (Los Angeles, CA, USA). The maximal binding of radiolabeled T4 measured in the plasma of vehicle or fiproniltreated thyroidectomized rats from experiment 2 was identical to the maximal 
binding at point 0 of the standard curve. This implies that the potential presence of fipronil and/or its metabolites did not cause major interference in the T4 assay. TSH plasma concentrations were measured by RIA kit (GE Healthcare, Buc, France). All assays were performed according to the manufacturer's instructions. Samples from experiment 2 were assayed in duplicate. The samples from the kinetic studies were assayed without replicates. The mean intra-assay coefficients of variation for 3 quality control (QC) pools were less than $8 \%$ for total T4, free T4, total T3 and TSH concentrations. The mean inter-assay coefficients of variation for $3 \mathrm{QC}$ pools were less than $13 \%$ for total T4, free T4, total T3 and TSH concentrations. The limit of quantification of the total T4 assay was $5 \mathrm{ng} / \mathrm{ml}$. The limit of quantification for the other assays was set at the lowest value of the standard curve.

\subsection{Fipronil and fipronil sulfone assay}

Fipronil and fipronil sulfone plasma concentrations were determined by HPLC coupled with a UV detection method after solid phase extraction of $150 \mu \mathrm{l}$ of plasma spiked with $75 \mathrm{ng}$ of Internal Standard (IS) (2-(4-chlorophenyl)-5-methyl$2 \mathrm{H}$-pyrazol-3-ylamine, $1 \mu \mathrm{g} / \mathrm{ml}$ ) on a SPE cartridge (Bond Elut C8 Varian ${ }^{\circledR} 100 \mathrm{mg}$, Les Ulis, France). The cartridge was washed with $1 \mathrm{ml}$ of water-acetonitrile (95/5, $\mathrm{v} / \mathrm{v}$ ) and the analytes were eluted with $1 \mathrm{ml}$ of methanol. The extract was dried at $40{ }^{\circ} \mathrm{C}$ under nitrogen vapour and reconstituted in $75 \mu \mathrm{l}$ of water-methanol (50:50, $\mathrm{v} / \mathrm{v}$ ). The analyses were performed on a Kontron (Paris, France) chromatographic system. The mobile phase (methanol-acetic acid $0.005 \mathrm{~N}(67: 33, \mathrm{v} / \mathrm{v})$ ) was pumped at a flow rate of $0.4 \mathrm{ml} / \mathrm{min}$. The column (Nucleosil ${ }^{\circledR} \mathrm{C} 18,3 \mu \mathrm{m}, 125 \mathrm{~mm} \times 4 \mathrm{~mm}$ with a C18 $10 \mu \mathrm{m}$ guard column, Bischoff, Germany) was maintained at $40^{\circ} \mathrm{C}$. Peaks were monitored by UV absorbance at $275 \mathrm{~nm}$. Mean recovery calculated for IS was $86 \%$. The standard curve (from 100 to $2500 \mathrm{ng} / \mathrm{ml}$ ) was obtained by fitting the data (ratio area peak/area IS $v s$. theoretical concentrations) according to a linear equation using a linear regression model with $1 /$ (concentrations) $^{2}$ as weighting factor.

Three QC pools of 160,800 and $1600 \mathrm{ng} / \mathrm{ml}$ were used for the validation run. The mean within-day precisions for these 3 QC were less than $8.5 \%$ for fipronil and fipronil sulfone, and the mean between-day precisions were less than $7.5 \%$ for fipronil and $10 \%$ for fipronil sulfone. The accuracy was $97.09 \pm 1.75 \%$ for fipronil and $101.86 \pm 8.66 \%$ for fipronil sulfone. The limit of detection was set at the first point of the standard curve, i.e. $100 \mathrm{ng} / \mathrm{ml}$ for both fipronil and fipronil sulfone.

\subsection{Antipyrine assay}

Antipyrine plasma concentrations were determined by HPLC coupled with a UV detector method after solid phase extraction of $150 \mu \mathrm{l}$ of plasma spiked with $1 \mu \mathrm{g}$ of IS (acetophenetidin, $10 \mu \mathrm{g} / \mathrm{ml}$ ) on an SPE cartridge (Bond Elut C8 Varian $^{\circledR}$ $100 \mathrm{mg}$ ). Analytes were eluted with $1 \mathrm{ml}$ of dichloromethane-methanol (85:15, $\mathrm{v} / \mathrm{v})$. The extract was dried at $40^{\circ} \mathrm{C}$ under nitrogen and reconstituted in $100 \mu \mathrm{l}$ of water-methanol $(50: 50, \mathrm{v} / \mathrm{v})$. After centrifugation, $50 \mu \mathrm{l}$ of the supernatant were injected into a Kontron (Paris, France) chromatographic system. The mobile phase was a mixture of acetonitrile and phosphate buffer $25 \mathrm{mM}, \mathrm{pH} 7.2(25: 75, \mathrm{v} / \mathrm{v})$, pumped at a flow rate of $0.6 \mathrm{ml} / \mathrm{min}$ through the column (Inertsil ODS $3^{\circledR} \mathrm{C} 18,3 \mu \mathrm{m}$, $150 \mathrm{~mm} \times 4 \mathrm{~mm}$ with an Inertsil ODS3 ${ }^{\circledR} 10 \mathrm{~mm} \times 4 \mathrm{~mm}$ guard column) at $40^{\circ} \mathrm{C}$. Peaks were monitored by UV absorbance at $254 \mathrm{~nm}$. Data (ratio area peak/area IS $v$ s. theoretical concentrations) were fitted with a linear regression model with

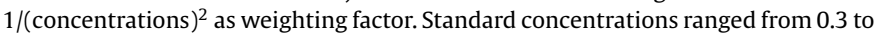
$40.0 \mu \mathrm{g} / \mathrm{ml}$. The calculated recovery for IS was $86 \%$. The mean within- and betweenday precisions for the 3 QC pools were less than $5 \%$. The accuracy was $98.3 \pm 0.67 \%$. The limit of detection was set at the lowest concentration of the standard curve, i.e. $0.3 \mu \mathrm{g} / \mathrm{ml}$.

\subsection{Pharmacokinetic analysis}

The pharmacokinetic analyses were performed by least-squares regression analysis using WinNonlin ${ }^{\circledR}$ software (WinNonlin ${ }^{\circledR}$ 5.2, Pharsight Corporation, CA, USA). Antipyrine, total and free T4 plasma concentrations over time were fitted using a monoexponential model with a first-order absorption phase according to Eq. (1):

$C(t)=\frac{F \times D \times K_{01}}{V \times\left(K_{01}-K_{10}\right)} \times\left(\exp \left(-K_{10} \times t\right)-\exp \left(-K_{01} \times t\right)\right)$

where $C(t)$ is the plasma concentration at time $t, F$ is the bioavailability of the drug, $D$ is the drug dose, $V$ is the volume of distribution $(\mathrm{ml} / \mathrm{kg}), K_{01}\left(\mathrm{~h}^{-1}\right)$ is the first-order rate constant of absorption and $K_{10}\left(\mathrm{~h}^{-1}\right)$ is the first-order rate constant of elimination. $V / F, K_{10}$ and $K_{01}$ were estimated. The data were weighted by the inverse of the squared-fitted value. The terminal half-life $\left(T_{1 / 2}\right)$ was defined as $\ln (2) / K_{10}$ and $T_{\max }$, time at the maximal concentration $\left(C_{\max }\right)$ as $\ln \left(K_{01} / K_{10}\right) /\left(K_{01}-K_{10}\right)$. The area under the concentration curve $v s$. time (AUC) from time zero to the last detectable concentration was calculated as AUC $=D /\left((V / F) \times K_{10}\right)$ with $(V / F) \times K_{10}$ being the apparent clearance (clearance/F)

\subsection{Statistical analysis}

For experiment 1, the effect of fipronil treatment on mean TH and TSH plasma concentrations was analyzed using a two-way ANOVA with treatment and duration as fixed-effect factors. This was performed using R software (version 2.4.1, R Development Core Team, Vienna, Austria). The effect of fipronil treatment on mean antipyrine, free and total T4 PK parameters and UDPGT activities was analyzed by Student's $t$-test.

\section{Results}

\subsection{Characterization of fipronil and fipronil sulfone exposure}

The plasma concentrations of fipronil and fipronil sulfone observed at the end of the first three experiments are listed in Table 1. Fipronil levels were below the limit of quantification of the assay in all the experiments. The animals appeared to be much more exposed to the sulfone metabolite than to the parent compound fipronil (at least 20-fold).

\subsection{Experiment 1: effect of fipronil on TH and TSH concentrations}

The body weights of rats in the control and fipronil-treated groups at the end of the experiment were similar (mean BW \pm S.D.: $267 \pm 14 \mathrm{~g} v$ s. $269 \pm 8 \mathrm{~g}$ for the control and fipronil-treated groups, respectively). Fig. 1 shows the mean $( \pm$ S.D.) TSH, total and free $\mathrm{T} 4$ and T3 plasma concentrations in control and fipronil-treated groups after 14 and 28 days of treatment. Fipronil treatment was associated with a significant decrease in total T4 and T3 plasma concentrations (treatment effect $p<0.02$ and $p<0.01$ for T4 and T3, respectively). T3 and T4 plasma concentrations were 23 and $26 \%$ lower in fipronil-treated animals as compared to the control group after 14 days of treatment. Free TH concentrations were also significantly decreased by fipronil treatment. Fipronil treatment was associated with an increase in plasma TSH concentrations $(p<0.05)$. There was no significant interaction between the treatment and its duration ( $p>0.27$ for total and free TH and TSH) indicating that the fipronil effect had already occurred during the first 14 days of treatment.

\subsection{Experiment 2: effect of fipronil on T4 PK parameters}

Fig. 2 depicts the time course of the mean ( \pm S.D.) total and free T4 plasma concentrations in control and fipronil-treated groups. Visual inspection of the graphs shows that the mean total and free T4 concentrations are higher in the control group for each time point. Estimated T4 PK final parameters are presented in Table 2. Mean total T4 AUC, $T_{1 / 2}$ and $C_{\max }$ were significantly lower $(p<0.01)$ in the fipronil-treated group. $T_{\max }$ did not differ between groups. In contrast, the apparent clearance in the fipronil-treated group was

Table 1

Mean ( \pm S.D.) fipronil and fipronil sulfone plasma concentrations at the end of the fipronil treatment in the first 3 different experiments.

\begin{tabular}{|c|c|c|c|c|}
\hline & Experiment 1 , day $14, n=7$ & Experiment 1 , day $28, n=7$ & Experiment $2, n=8$ & Experiment $3, n=9$ \\
\hline Fipronil plasma concentration (ng/ml) & $<100$ & $<100$ & $<100$ & $<100$ \\
\hline Fipronil sulfone plasma concentration (ng/ml) & $2544 \pm 219$ & $2482 \pm 296$ & $1445 \pm 132$ & $1974 \pm 274$ \\
\hline
\end{tabular}

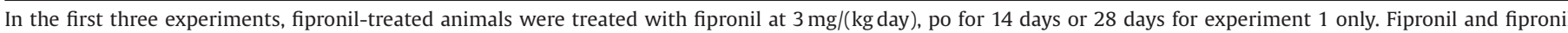

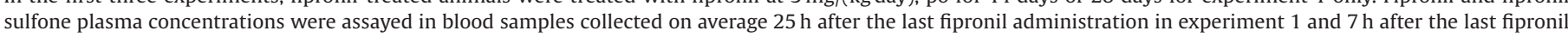
administration in experiments 2 and 3 . 

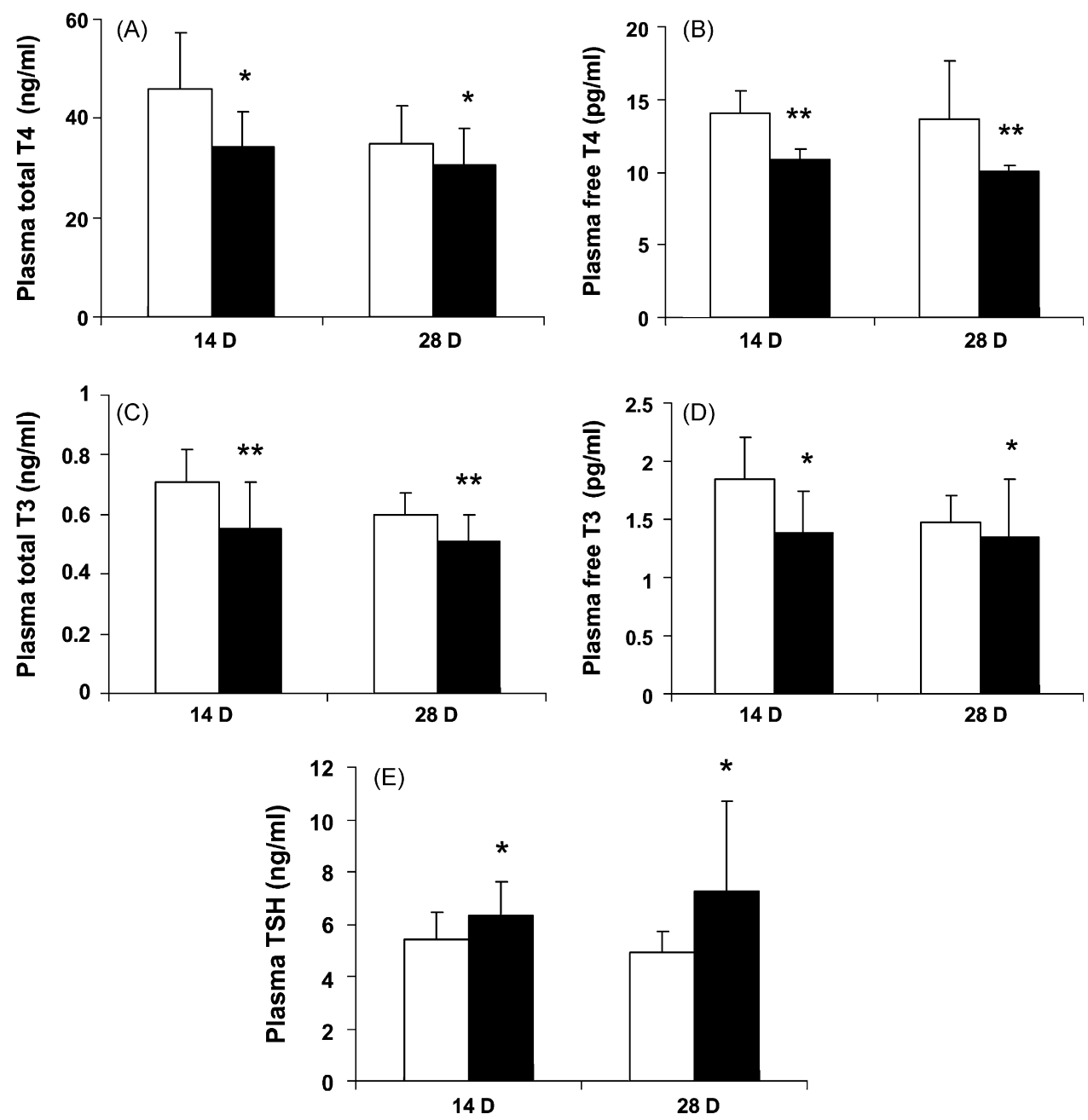

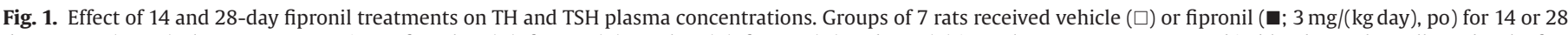

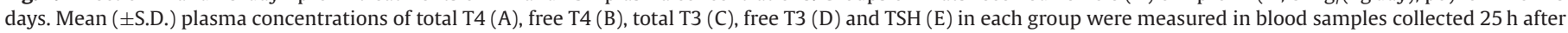
the last fipronil administration. Significantly different from control: ${ }^{*} p<0.05,{ }^{* *} p<0.01$.

twofold higher than in the control group. The same results were found for the free T4 PK parameters.

Total and free T4 plasma concentrations measured in blood samples collected before T4 administration were undetectable con-

Table 2

Effect of fipronil on mean $( \pm$ S.D.) total and free T4 PK parameters.

\begin{tabular}{lcc}
\hline & Control $n=10$ & Fipronil $n=7$ \\
\hline Total T4 & \\
AUC (ng h/ml) & $1131 \pm 263$ & $459 \pm 142^{* *}$ \\
Apparent clearance (ml/(min kg)) & $0.16 \pm 0.04$ & $0.40 \pm 0.13^{* *}$ \\
Terminal half-life (h) & $11.3 \pm 2.4$ & $7.6 \pm 2.5^{* *}$ \\
$C_{\max }(\mathrm{ng} / \mathrm{ml})$ & $58.9 \pm 6.9$ & $33.1 \pm 4.1^{* *}$ \\
$T_{\max }(\mathrm{h})$ & $2.6 \pm 0.7$ & $2.4 \pm 0.7$ \\
Free T4 & & \\
AUC (ng h/ml) & $287 \pm 70$ & $123 \pm 42^{* *}$ \\
Apparent clearance (ml/(min kg)) & $618 \pm 170$ & $1460 \pm 389^{* *}$ \\
Terminal half-life (h) & $9.6 \pm 1.8$ & $6.8 \pm 1.6^{* *}$ \\
$C_{\max }(\mathrm{ng} / \mathrm{ml})$ & $16.7 \pm 3.2$ & $9.2 \pm 2.1^{* *}$ \\
$T_{\max }(\mathrm{h})$ & $2.8 \pm 0.7$ & $2.8 \pm 1.1$ \\
\hline
\end{tabular}

T3-treated $(12 \mu \mathrm{g} /(\mathrm{kg}$ day $), \mathrm{sc})$ THX rats were treated with vehicle $(n=10)$ or fipronil ( $3 \mathrm{mg} /(\mathrm{kg}$ day), po; $n=8$ ) for 14 days. One day after the last fipronil administration, total and free T4 concentrations were measured in blood samples collected at 0.25 , $1,2,4,8,23$ and $28 \mathrm{~h}$ after a single T4 i.p. administration $(10 \mu \mathrm{g} / \mathrm{kg})$. Total and free T4 PK parameters were calculated with a monoexponential model for each animal. Significantly different from control: $p<0.01$. firming the T4-free status of the animals. Mean ( \pm S.D.) total T3 plasma concentrations measured on the day of the T4 kinetics, i.e. $6 \mathrm{~h}$ after $\mathrm{T} 3 \mathrm{sc}$ injection and $5 \mathrm{~h}$ after T4 i.p. administration were significantly lower in the fipronil-treated group $(0.9 \pm 0.3$ and $1.4 \pm 0.3 \mathrm{ng} / \mathrm{ml}$ for fipronil-treated and control groups respectively, $p<0.01)$.

\subsection{Experiment 3: effect of fipronil on antipyrine PK parameters}

Fig. 3 depicts the time course of the mean ( \pm S.D.) plasma antipyrine concentrations in the control and fipronil-treated groups. Visual inspection of the graph shows that the mean plasma antipyrine concentrations are higher for each time point in the control group. The estimated final antipyrine PK parameters are presented in Table 3 . Mean AUC, $T_{1 / 2}$ and $C_{\max }$ were significantly lower $(p<0.01)$ in the fipronil-treated group whereas the apparent clearance was about twofold higher in the fipronil-treated group than in the control group.

\subsection{Experiment 4: effect of fipronil on UDPGT activity toward 4-nitrophenol}

Mean UDPGT activity ( \pm S.D.) toward 4-nitrophenol in the fipronil-treated group was $71 \pm 13 v s .56 \pm 8 \mathrm{nmol} /(\mathrm{h} \mathrm{mg})$ for the 

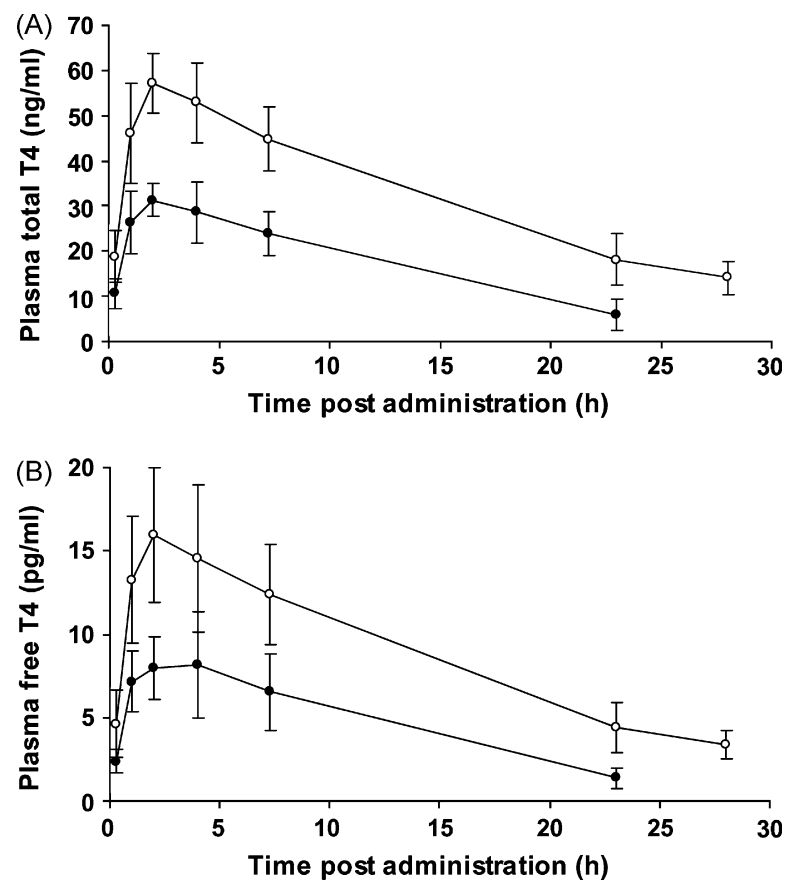

Fig. 2. Effect of fipronil on the time course of the disposition of total and free T4 plasma concentrations. T3-treated $(12 \mu \mathrm{g} /(\mathrm{kg}$ day $), \mathrm{sc})$ thyroidectomized rats were administered vehicle ( $\bigcirc ; n=10$ ) or fipronil ( $\bullet 3 \mathrm{mg} /(\mathrm{kg}$ day), po; $n=8)$ for 14 days. One day after the last fipronil administration, total and free T4 concentrations were measured in blood samples collected at $0.25,1,2,4,8,23$ and $28 \mathrm{~h}$ after a single T4 i.p. administration $(10 \mu \mathrm{g} / \mathrm{kg})$. (A) Mean $( \pm$ S.D.) total T4 concentrations $v$ s. time; (B) mean ( \pm S.D.) free T4 concentrations $v s$. time.

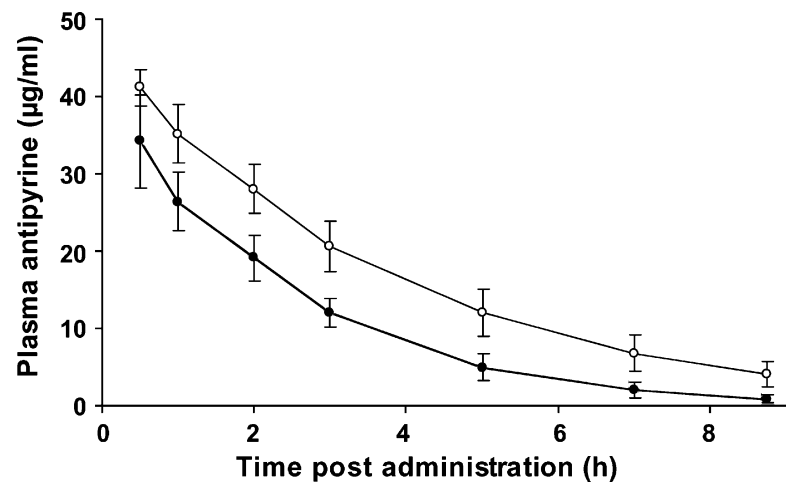

Fig. 3. Effect of fipronil on the time course of disposition of mean ( \pm S.D.) plasma antipyrine concentrations. Rats were treated with vehicle $(\bigcirc ; n=8)$ or fipronil ( $3 \mathrm{mg} /(\mathrm{kg}$ day), po; $n=9$ ) for 14 days. One day after the last administration, plasma antipyrine concentrations were monitored $0.5,1,2,3,5,7$ and $9 \mathrm{~h}$ after a single antipyrine i.p. administration ( $30 \mathrm{mg} / \mathrm{kg})$.

Table 3

Effect of fipronil on mean ( \pm S.D.) antipyrine PK parameters.

\begin{tabular}{lcc}
\hline & Control $n=8$ & Fipronil $n=9$ \\
\hline Antipyrine & & \\
AUC $(\mu \mathrm{g} \mathrm{h} / \mathrm{ml})$ & $166 \pm 28$ & $95 \pm 19^{* *}$ \\
Apparent clearance $(\mathrm{ml} /(\mathrm{min} \mathrm{kg}))$ & $3.1 \pm 0.7$ & $5.4 \pm 1.0^{* *}$ \\
Terminal half-life $(\mathrm{h})$ & $2.4 \pm 0.5$ & $1.5 \pm 0.2^{* *}$ \\
$C_{\max }(\mu \mathrm{g} / \mathrm{ml})$ & $41.5 \pm 2.5$ & $35.6 \pm 7.1^{* *}$ \\
\hline
\end{tabular}

Rats were treated with vehicle $(n=8)$ or fipronil ( $3 \mathrm{mg} /(\mathrm{kg}$ day), po; $n=9$ ) for 14 days. One day after the last administration, plasma antipyrine concentrations were measured in blood samples collected at $0.5,1,2,3,5,7$ and $9 \mathrm{~h}$ after a single antipyrine i.p. administration $(30 \mathrm{mg} / \mathrm{kg})$. Antipyrine PK parameters were calculated with a monoexponential model.

** Significantly different from control: $p<0.01$. control group showing a significant $28 \%$ increase $(p<0.01)$ of 4 nitrophenol UDPGT activity in fipronil-treated group.

\section{Discussion}

Our study clearly demonstrated that fipronil decreases T4 concentrations by increasing T4 clearance. We showed that fipronil treatment decreases total T4 plasma concentrations and increases TSH plasma concentrations, which is in agreement with results of previous non-peer reviewed toxicological studies (FAO/WHO, 1997; Hurley, 1998; Tingle et al., 2003). In addition, we also showed that fipronil decreases total $\mathrm{T} 3$ and free $\mathrm{TH}$ plasma concentrations in thyroid-intact rats. Our results indicate that the decrease in total and free TH plasma concentrations are associated with an increase in both total and free T4 clearances. Moreover, it seems likely that fipronil can induce phase I and phase II hepatic enzymes, a hypothesis supported by the twofold increase in antipyrine clearance in vivo and the increased microsomal UDPGT activity toward 4-nitrophenol. Further work using mRNA analyses is required to definitely validate this hypothesis and clearly identify the enzymes induced. Altogether, our results are consistent with the general pathophysiological scheme of action of fipronil proposed from earlier toxicological studies, but the present study is the first in which all these results were obtained under the same conditions of fipronil treatment.

To determine the effect of fipronil on both total and free T4 clearances, a T4-free euthyroid-like model was developed to monitor simultaneously the decrease of free and total T4 concentrations following a single i.p. administration of exogenous T4. All sources of endogenous T4 were removed by thyroidectomy and daily Sc injections of $\mathrm{T} 3$ were administered in order to obtain $\mathrm{T} 3$ concentrations as close as possible to physiological T3 concentrations. In this model, it was critical to maintain a euthyroid-like state for two main reasons. First, fipronil is a substrate of CYP enzymes, mainly CYP3A4 (Tang et al., 2004), which are regulated in part by TH, particularly T3 (Liddle et al., 1998; Oinonen and Lindros, 1998). The maintenance of a physiologically relevant thyroid status was therefore a sine qua non condition to obtain comparable fipronil and fipronil sulfone exposures in all experiments. Secondly, a euthyroid-like state was critical to prevent re-expression of thyroxine-binding globulin (TBG), the major transport protein of TH in humans (Schussler, 2000), not expressed in the adult rat (Savu et al., 1991) but reexpressed in THX rats (Vranckx et al., 1994). As TBG is assumed to play a protective role against $\mathrm{TH}$ disruption resulting from an increase in TH catabolism (Hard, 1998; Hurley, 1998), this lack of TBG is considered as a major limit of the rat model for the evaluation of potential thyroid disruptors for human health. Total T3 plasma concentrations in the T3-treated THX control group were slightly higher than those observed in the thyroid-intact control group of experiment 1 . These values remained however within the physiological range. Furthermore, apparent clearance of T4 in the control group was consistent with values from previous studies (DiStefano and Feng, 1988; Yamada et al., 1996) showing the physiological relevance of our model. In experiment 2, total T3 plasma concentrations were higher in the control group than in the fipronil-treated group which is consistent with the effect of fipronil observed on T3 plasma concentrations in thyroid-intact rats (experiment 1) and suggests that T3 clearance might also be increased by fipronil treatment.

The ex vivo and in vitro data concerning the ability of fipronil to induce hepatic enzymes are conflicting. In vitro, fipronil increases CYP1A1 and 3A4 activities in human hepatocytes (Das et al., 2006) whereas no clear effect of fipronil was evidenced on the activities of microsomes obtained from fipronil-treated rats, rabbits or mice (1.2 or $5 \mathrm{mg} /(\mathrm{kg}$ day) for 4 or 14 days) (AFSSA, 2005). In this 
study, we evaluated the effect of fipronil on the activity of both phase I and of some UDPGT involved in T4 glucuronidation. The effect of fipronil on the activity of phase I hepatic enzymes was studied in vivo by assessing the effect of fipronil on antipyrine clearance which is considered as a relevant biomarker to evaluate the activity of phase I hepatic enzymes in different species (St Peter and Awni, 1991; Carcillo et al., 2003; Chan and Yeung, 2006). The twofold in vivo increase in antipyrine apparent clearance observed in experiment 3 is consistent with an increase in the activity of CYP enzymes implicated in antipyrine metabolism (Szakacs et al., 2001; Balani et al., 2002). Such an increase in CYP enzyme activity might be due to a direct induction of gene expression as demonstrated with human hepatocytes in which fipronil induces an increase in both gene expression and activities of CYP1A1 and 3A4 isoforms (Liddle et al., 1998; Das et al., 2006). Several CYP enzymes involved in xenobiotic and hormone metabolism are regulated by the pregnane X-receptor (PXR) and/or the constitutive androstane receptor (CAR) (Kretschmer and Baldwin, 2005). Fipronil has been shown to be a ligand of the human PXR in vitro (Lemaire et al., 2006). Further investigations are required to determine the involvement of the CAR/PXR pathway in fipronil-mediated thyroid disruption and CYP induction.

We also investigated the effect of fipronil on one type of UDPGT activity involved in T4 glucuronidation: UDPGT activity toward 4 -nitrophenol. The response of 4-nitrophenol UDPGT activity to several microsomal enzyme inducers is representative of T4 UDPGT activity (Visser et al., 1993b). 4-Nitrophenol UDPGT activity was increased in microsomal hepatic fractions from rats treated with fipronil indicating an increased activity of UGT1 isoforms, in particular UGT1A6 (Ikushiro et al., 2002). Such an increase in UDPGT activity could explain, at least in part, the increase in T4 clearance evidenced in our study and is consistent with the increased T4 biliary elimination demonstrated in toxicological studies (FAO/WHO, 1997). The involvement of other pathways of T4 elimination such as sulfation, deiodination or increased excretion of unconjugated T4 (Wong et al., 2005) cannot be excluded. Furthermore, it would be interesting to evaluate the potential impact of increased activity of CYP enzymes on T4 clearance.

In the present study, fipronil sulfone rather than fipronil was the major substance to which rats were exposed during fipronil treatment. Fipronil sulfone is the main fipronil metabolite in both humans and rats. However, the rate of fipronil sulfone formation is about fourfold higher in rat liver microsomes than in human ones (Tang et al., 2004). A very high rate of fipronil metabolism in rats is consistent with our results (unpublished data) showing that fipronil sulfone appears in blood within $2 \mathrm{~h}$ after fipronil oral administration. Accidental human exposure to fipronil has indicated that the ratio of fipronil sulfone/fipronil plasma concentrations at $24 \mathrm{~h}$ post-ingestion is about $0.25-0.5$ (Mohamed et al., 2004). In our conditions, this value was higher than 20 in the rat after 14 days of exposure. Quantitative differences in fipronil metabolism might therefore exist between the two species. This questions the relevance of using the rat model, as is generally required by regulatory authorities, to evaluate the risk of human exposure to this toxicant. Further investigations are required to determine the contribution of fipronil sulfone to the toxicological effects observed which underlines the importance of characterizing the exposure to the toxicant and its metabolites in toxicological studies.

In conclusion, fipronil treatment leads to thyroid disruption in the rat characterized by a decrease in TH plasma concentrations resulting from a large increase in TH clearance. However, the relevance of these results in the context of human risk is not straightforward because TBG is expressed in humans but not in adult rats and the relative exposure to fipronil and fipronil sulfone might differ between the two species. Confirmation or invalidation of the risk of fipronil as a thyroid disruptor in humans would require further investigations in a species in which thyroid regulation and fipronil metabolism are similar to those of humans.

\section{Conflict of interest}

The authors declare that there are no conflicts of interest.

\section{Acknowledgements}

The authors thank Dr Jean-Pierre Cravedi and Dr Anne Hillenweck for their technical support and help in revising the manuscript and Sylvie Puel for validating and performing the HPLC assays.

Funding: French National Institute for Agronomical Research (INRA); French Ministry of Ecology and Sustainable Development (PNRPE 0000442).

\section{References}

Abend, S.L., Fang, S.L., Alex, S., Braverman, L.E., Leonard, J.L., 1991. Rapid alteration in circulating free thyroxine modulates pituitary type II $5^{\prime}$ deiodinase and basal thyrotropin secretion in the rat. J. Clin. Invest. 88, 898-903.

AFSSA, 2005. Évaluation des risques pour la santé humaine liés à une exposition au fipronil.

Balani, S.K., Zhu, T., Yang, T.J., Liu, Z., He, B., Lee, F.W., 2002. Effective dosing regimen of 1-aminobenzotriazole for inhibition of antipyrine clearance in rats, dogs, and monkeys. Drug Metab. Dispos. 30, 1059-1062.

Burchell, B., Weatherill, P., 1981. 4-Nitrophenol UDPglucuronyltransferase (rat liver). Methods Enzymol. 77, 169-177.

Carcillo, J.A., Doughty, L., Kofos, D., Frye, R.F., Kaplan, S.S., Sasser, H., Burckart, G.J., 2003. Cytochrome P450 mediated-drug metabolism is reduced in children with sepsis-induced multiple organ failure. Intensive Care Med. 29, 980-984.

Chan, S.L., Yeung, J.H., 2006. Modulation of antipyrine clearance by polysaccharide peptide (PSP) isolated from Coriolus versicolor in the rat. Food Chem. Toxicol. 44, 1607-1612.

Das, P.C., Cao, Y., Cherrington, N., Hodgson, E., Rose, R.L., 2006. Fipronil induces CYP isoforms and cytotoxicity in human hepatocytes. Chem. Biol. Interact. 164, $200-214$.

DiStefano III., J.J., Feng, D., 1988. Comparative aspects of the distribution, metabolism, and excretion of six iodothyronines in the rat. Endocrinology 123, 2514-2525.

FAO/WHO, 1997. Pesticide Residues in Food-Fipronil.

Hard, G.C., 1998. Recent developments in the investigation of thyroid regulation and thyroid carcinogenesis. Environ. Health Perspect. 106, 427-436.

Hood, A., Hashmi, R., Klaassen, C.D., 1999. Effects of microsomal enzyme inducers on thyroid-follicular cell proliferation, hyperplasia, and hypertrophy. Toxicol. Appl. Pharmacol. 160, 163-170.

Hurley, P.M., 1998. Mode of carcinogenic action of pesticides inducing thyroid follicular cell tumors in rodents. Environ. Health Perspect. 106, 437-445.

Ikushiro, S., Emi, Y., Iyanagi, T., 2002. Activation of glucuronidation through reduction of a disulfide bond in rat UDP-glucuronosyltransferase 1A6. Biochemistry 41, 12813-12820.

Kretschmer, X.C., Baldwin, W.S., 2005. CAR and PXR: xenosensors of endocrine disrupters? Chem. Biol. Interact. 155, 111-128.

Lemaire, G., Mnif, W., Pascussi, J.M., Pillon, A., Rabenoelina, F., Fenet, H., Gomez, E., Casellas, C., Nicolas, J.C., Cavailles, V., Duchesne, M.J., Balaguer, P., 2006. Identification of new human pregnane $\mathrm{X}$ receptor ligands among pesticides using a stable reporter cell system. Toxicol. Sci. 91, 501-509.

Liddle, C., Goodwin, B.J., George, J., Tapner, M., Farrell, G.C., 1998. Separate and interactive regulation of cytochrome $\mathrm{P} 4503 \mathrm{~A} 4$ by triiodothyronine, dexamethasone, and growth hormone in cultured hepatocytes. J. Clin. Endocrinol. Metab. 83, 2411-2416.

Lowry, O.H., Rosebrough, N.J., Farr, A.L., Randall, R.J., 1951. Protein measurement with the Folin phenol reagent. J. Biol. Chem. 193, 265-275.

Matthew, D.E., Houston, J.B., 1990. Drug metabolizing capacity in vitro and in vivo. II. Correlations between hepatic microsomal monooxygenase markers in phenobarbital-induced rats. Biochem. Pharmacol. 40, 751-758.

Mohamed, F., Senarathna, L., Percy, A., Abeyewardene, M., Eaglesham, G., Cheng, R., Azher, S., Hittarage, A., Dissanayake, W., Sheriff, M.H., Davies, W., Buckley, N.A., Eddleston, M., 2004. Acute human self-poisoning with the N-phenylpyrazole insecticide fipronil-a GABAA-gated chloride channel blocker. J. Toxicol. Clin. Toxicol. 42, 955-963.

Oinonen, T., Lindros, K.O., 1998. Zonation of hepatic cytochrome P-450 expression and regulation. Biochem. J. 329 (Pt 1), 17-35.

Savu, L., Vranckx, R., Rouaze-Romet, M., Maya, M., Nunez, E.A., Treton, J., Flink, I.L., 1991. A senescence up-regulated protein: the rat thyroxine-binding globulin (TBG). Biochim. Biophys. Acta 1097, 19-22. 
Schussler, G.C., 2000. The thyroxine-binding proteins. Thyroid 10, 141-149.

St Peter, J.V., Awni, W.M., 1991. Quantifying hepatic function in the presence of liver disease with phenazone (antipyrine) and its metabolites. Clin. Pharmacokinet. 20, 50-65.

Szakacs, T., Veres, Z., Vereczkey, L., 2001. Effect of phenobarbital and spironolactone treatment on the oxidative metabolism of antipyrine by rat liver microsomes. Pol. J. Pharmacol. 53, 11-19.

Tanaka, E., Kobayashi, S., Aramphongphan, A., Kurata, N., Oguchi, K., Kuroiwa, Y. Yasuhara, H., 1985. The effect of indomethacin on hepatic drug-oxidizing capacity in the rat: trimethadione and antipyrine metabolism as an indicator. J. Pharmacobiodyn. 8, 773-779.

Tang, J., Amin Usmani, K., Hodgson, E., Rose, R.L., 2004. In vitro metabolism of fipronil by human and rat cytochrome P450 and its interactions with testosterone and diazepam. Chem. Biol. Interact. 147, 319-329.

Tingle, C.C., Rother, J.A., Dewhurst, C.F., Lauer, S., King, W.J., 2003. Fipronil: environmental fate, ecotoxicology, and human health concerns. Rev. Environ. Contam. Toxicol. 176, 1-66.

Visser, T.J., Kaptein, E., van Raaij, J.A., Joe, C.T., Ebner, T., Burchell, B., 1993a. Multiple UDP-glucuronyltransferases for the glucuronidation of thyroid hormone with preference for 3,3', 5'-triiodothyronine (reverse T3). FEBS Lett. 315, 65-68.

Visser, T.J., Kaptein, E., van Toor, H., van Raaij, J.A., van den Berg, K.J., Joe, C.T., van Engelen, J.G., Brouwer, A., 1993b. Glucuronidation of thyroid hormone in rat liver: effects of in vivo treatment with microsomal enzyme inducers and in vitro assay conditions. Endocrinology 133, 2177-2186.

Vranckx, R., Rouaze-Romet, M., Savu, L., Mechighel, P., Maya, M., Nunez, E.A., 1994. Regulation of rat thyroxine-binding globulin and transthyretin: studies in thyroidectomized and hypophysectomized rats given tri-iodothyronine or/and growth hormone. J. Endocrinol. 142, 77-84.

Williams, E.D., 1995. Mechanisms and pathogenesis of thyroid cancer in animals and man. Mutat. Res. 333, 123-129.

Wong, H., Lehman-McKeeman, L.D., Grubb, M.F., Grossman, S.J., Bhaskaran, V.M. Solon, E.G., Shen, H.S., Gerson, R.J., Car, B.D., Zhao, B., Gemzik, B., 2005. Increased hepatobiliary clearance of unconjugated thyroxine determines DMP 904induced alterations in thyroid hormone homeostasis in rats. Toxicol. Sci. 84, 232242.

Yamada, H., Distefano III., J.J., Yen, Y.M., Nguyen, T.T., 1996. Steady-state regulation of whole-body thyroid hormone pool sizes and interconversion rates in hypothyroid and moderately T3-stimulated rats. Endocrinology 137, 5624 5633.

Zalko, D., Prouillac, C., Riu, A., Perdu, E., Dolo, L., Jouanin, I., Canlet, C., Debrauwer, L., Cravedi, J.P., 2006. Biotransformation of the flame retardant tetrabromobisphenol A by human and rat sub-cellular liver fractions. Chemosphere 64 318-327. 